\title{
EXPLORING THE RELATIONSHIP BETWEEN THE CREATION OF AN INTERMODAL PASSENGER TERMINAL AND THE URBAN DEVELOPMENT OF DEBRECEN: A CASE STUDY
}

\author{
BALÁZS BODNÁR ${ }^{1}$, GYÖRGY CSOMÓs² \\ ${ }^{1}$ University of Debrecen, Debrecen, Hungary \\ ${ }^{2}$ Department of Civil Engineering University of Debrecen, Hungary
}

Manuscript received: December 7, 2018

Revised version: March 15, 2019

\begin{abstract}
BodNÁr B., Csomós G., 2019. Exploring the relationship between the creation of an intermodal passenger terminal and the urban development of Debrecen: A case study. Quaestiones Geographicae 38(2), Bogucki Wydawnictwo Naukowe, Poznań, pp. 101-119. 2 tables, 4 figs.

AвSTRACT: In the EU programming period of 2014-2020, Hungary's largest-ever transport development project, an intermodal passenger terminal (IPT), is planned to be built in Debrecen. The IPT will integrate all public transport modes operating in Debrecen in a single building, with the modes being as follows: railways, long-distance and local buses, trolley-buses and trams. In addition, by creating a large number of parking spaces for cars, and by building lanes for bicycles and pedestrians heading into the facility, the public transport and individual transport modes will be directly connected under the roof of the IPT. The IPT development will be accompanied by large-scale urban renewal projects to revitalise Petófi square, one of Debrecen's major public spaces, lying in front of the building. Relating to the IPT development, several feasibility studies and sustainability analyses have been performed; however, the impact of the IPT on the development of Debrecen has not previously been examined. The main goal of this paper is to examine whether IPT development contributes to the enhancement of Debrecen's central position in its agglomeration, the strengthening of Debrecen's competitiveness in Hungary's urban system, the spatial decentralisation of the city's cultural activities and how it may influence the change of Debrecen's socio-economic factors.
\end{abstract}

KEY WORDS: intermodality, public transport, urban development, Debrecen

Corresponding author: György Csomós, Department of Civil Engineering University of Debrecen, 2-4 Otemeto u., Debrecen, 4028, Hungary, e-mail: csomos@eng.unideb.hu

\section{Introduction}

In recent years, the development of intermodal transport facilities has become one of the major instruments of urban transport development policies worldwide, but primarily in Europe (Ghaderi et al. 2016; de Langen et al. 2017; Sugawara 2017). In the EU programming period of 2014-2020, Hungary's largest-ever transport development project, an intermodal passenger terminal (IPT) is planned to be built in Debrecen. Regarding the feasibility, operation, maintenance and sustainability of the IPT, several studies and analyses have been performed, but none of them explores the impacts of the IPT on the urban development of Debrecen.

The intermodal passenger transport concept, which is based upon the integration of different transport modes, gained significant interest in transport development policies at the beginning 
of the 21st century (Bontekoning et al. 2004; Nobis 2007; Dacko, Spalteholz 2014). The main aims of the implementation of the intermodal approach are to reduce urban traffic congestions, optimise the size of the city's transport areas and shorten travellers' time required for changing transport modes. To achieve these aims, intermodal passenger terminals (in different contexts also termed multimodal transport hubs, passenger transport facilities, central railway stations, etc.) are being developed around the world. In several European cities, the municipalities finance IPT projects from their own budgets, and in some cases additional business-based funding is required, but most generally IPT projects require the financial support of the European Union (Heddebaut, Palmer 2014). European IPT developments are often implemented along with other functions complementing transport functions because in many cases, IPTs are created by rebuilding central railway stations, and the future functions of IPTs will reflect the varying features of cities they are located in and the demands of visitors (Bertolini, Dijst 2003). Besides the essential transport functions, these features and demands generate requirements for additional functions such as shopping, recreation, entertainment, as well as business and office functions. According to Bertolini (1996), the dual role of railway stations has strengthened: on the one hand, railway stations are nodes of transport, and on the other hand they are urban places having general urban functions. Thus, IPTs are considered to be special urban places where different transport modes are connected, but also as interfaces between city transport and urban functions.

In Europe, two important factors have influenced the development of IPTs. The first one is in relation to the general improvement of the infrastructure in the Europe Union: since the late 1950s, the European Union (and its predecessors) has dedicated particular attention to the creation of the Trans-European Transport Networks (TEN-T). Since the 1970s, intercity high-speed rail services have been put into operation in several European countries, including the TGV in France, the ICE in Germany and the AVE in Spain. By increasing passenger capacities, providing additional convenience services for passengers, shortening travel time and increasing safety, these infrastructure developments have significantly contributed to the appreciation of rail transport, making it competitive with other transport modes (Givoni 2006). Secondly, in recent decades, large and growing suburban zones in terms of size and population have formed surrounding major European cities, and these multifunctional urban areas generate an increasing demand to connect suburban public transport systems with the local public transport system of the central city.

Since 2007, the financial instruments of the EU cohesion policy (the Structural Funds and the Cohesion Fund) have given significant impetus to the Member States' transport development actions, including intermodal transport developments. In the EU programming period of 20142020, a total budget of more than 58 billion euros (not including national co-financing) is available for investments in the network infrastructure in transport and energy (ESIF Data 2018). Moreover, not only does the support of financial instruments foster IPT development, but also the introduction of standardised strategic planning requirements at the Community level. General transport development strategies, concepts and guidelines issued by the EU highlight the importance of IPT developments. According to the Europe 2020 Strategy, the focus should be on the urban dimension of transport where much of the congestion and emissions are generated (EC 2010: 16) ${ }^{1}$. The White Paper highlights that better modal choices will result from greater integration of the modal networks; airports, ports, railway, metro and bus stations, should increasingly be linked and transformed into multimodal connection platforms for passengers (EC 2011: 6) ${ }^{2}$. Finally, the Green Paper proposes that there is a growing requirement for developing guidance on intermodal terminals for collective transport (EC 2007: 14) $)^{3}$.

Thanks to the financial support of the EU and the adaptation of the Community's intermodal approach, all possibilities are open for Hungary to implement IPT developments. In the EU

European Commission, 2010: EUROPE 2020: A strategy for smart, sustainable and inclusive growth. Brussels, 3.3.2010, COM(2010) 2020 final.

2 European Commission, 2011: WHITE PAPER: Roadmap to a Single European Transport Area - Towards a competitive and resource efficient transport system. Brussels, 28.3.2011, COM(2011) 144 final.

European Commission, 2007: GREEN PAPER: Towards a new culture for urban mobility. Brussels, 25.9.2007 COM(2007) 551 final. 
programming period of 2014-2020, the Integrated Transport Development Operational Programme (ITOP) of Hungary provides a total budget of 73 billion Hungarian forints (approximately 225 million euros) to implement such projects. It should be noted that based on the strategies available on the Community, national and local levels, some cities (including Debrecen) proceeded to prepare the IPT project in the previous programming period (2007-2013) by working out feasibility studies, cost-benefit analyses, technical plans and by initiating the authorisation process. The novelty of the intermodal approach is perfectly reflected in the fact that the legal status of the IPT (a building having more functions than a railway station) in Hungary was regularised only in 2017. The Hungarian government designated the National Infrastructure Development Company, a fully state-owned enterprise, to implement IPT projects in Hungary.

The intermodal passenger terminal of Debrecen will offer a competitive alternative to individual car use. According to the plans, the public transport system operating in Debrecen will cover the entire area of the city (even the outer zones), and the whole system will be centred in the IPT, where passengers will have the possibility to change transport modes. The IPT will integrate all public transport modes operating in Debrecen into a single building, with the modes being: railway, long-distance and local buses, trolley-buses and trams; moreover, passengers will be able to reach the airport directly. In addition, by creating a large number of parking spaces for cars, and by building lanes for bicycles and for pedestrians heading into the facility, the public transport modes and individual transport modes will be directly connected under the roof of the IPT.

There is no doubt that the IPT will significantly contribute to the shaping of public transport habits. However, we seek to determine how the intermodal terminal will influence the urban development and everyday life of Debrecen. Our research questions are centred on four topics:

1. Through its transport and additional functions, will the IPT contribute to the enhancement of Debrecen's central position in its agglomeration?

2. If being home to the IPT, will Debrecen be more competitive compared to cities with similar hierarchical status?
3. Will the IPT have any impacts on the development of Debrecen's socio-economic features?

4. Will the IPT project and related urban renewal developments contribute to the enhancement of Debrecen's cultural polycentricity?

The scope of the research goes beyond the examination of the basic transport function of the IPT. The structure of the paper is as follows: In Section 2, we present those urban functions that justify the need for the implementation of the IPT project. In Section 3, the data and methodology are explained. Also in this section, we present some foreign case studies that serve as examples for the IPT project of Debrecen. In the next section, we analyse how the IPT project may impact the urban development of Debrecen. Finally, we draw conclusions.

\section{Factors triggering the development of the IPT in Debrecen}

Having more than 202,000 (2017) inhabitants, Debrecen is the second most populous city in Hungary, following Budapest, the capital city of the country. The population of the city peaked in the early 1990s by reaching 217,000 ; however, since 1993, with lesser fluctuations, it has been witnessing a population decrease (which is not as fast as that of Hungary). The city administration is committed to reverse this harmful tendency and the main goal is to increase the number of local residents to 250,000 (Trenecon 2016). In the following section, we highlight four urban functions of Debrecen which are not only the cornerstones of the city's development process, and can be the foundations of the population growth but are considered to be the triggering mechanism of comprehensive urban transport developments, including the IPT project.

\section{The local economy}

During the period of state socialism, the economy of Debrecen was characterised by light industry (primarily by food processing) and agricultural production, but since the 1960 s, less significant heavy industrial activities have been settled in the city. At the beginning of the 1990s, waves of privatisation were spreading all over Hungary. One of the first privatised companies in Debrecen 
was the Biogal Pharmaceutical Company sold to Israeli TEVA Pharmaceutical, and later the Roller Bearing Company was acquired by the Germanybased Schaeffler Group. Since the 2000s, new types of foreign investments have occurred in the city: in 2001, as a green-field investment, the National Instruments, an American multinational company, opened its first overseas factory in Debrecen, followed by the relocation of companies offering back office services worldwide (e.g. IT Services, and British Telecom), or services to the parent company (e.g. the Flowserve). In tandem with the occurrence of foreign service companies, several manufacturing companies, such as the Germanbased ThyssenKrupp, Krones, Continental and most recently, the BMW Group, have announced the building of a factory in Debrecen. The pharmaceutical industry has always had a key importance in the city's economy, which is now represented not only by the presence of TEVA, but also that of the Richter Gedeon Pharmaceutical Company. Richter Gedeon is one of Hungary's most innovative domestically owned companies having built two factories in Debrecen, both of which focus on biotechnology research and development. Most of these companies are located in one of Debrecen's six industrial parks, from which the Debrecen Regional and Innovation Industrial Park is the largest, being home to companies (including National Instruments and Schaeffler) that employ more than 9,000 people.

Debrecen International Airport, operated by Xanga Group, is one of the major hubs of the lowcost airline Wizz Air, and is the second-busiest airport in Hungary, having more than 284,000 registered passengers in 2016, 65 percent more than in the previous year.

Due to the good transport connections (highways, railways, airport), the presence of several types of educational institutions (including vocational schools and the University of Debrecen), and the business-friendly approach of the city administration, it is forecast that Debrecen will attract more investors in the near future. Fostering this process, one of the priorities in the programming period of 2014-2020 is the opening of the Southern Industrial Park planned to host companies employing a total number of 22,000 people.

As indicators of the development of the local economy, the professional services company, Deloitte Touche Tohmatsu, opened its office in
Debrecen in 2015, and in 2018, the Financial Times ranked Debrecen first of all small European cities for its FDI Strategy (The Financial Times 2018). According to Páthy (2017), Debrecen belongs to the group of 'Dynamic' Eastern cities showing rapid economic growth, and it is considered to be one of Hungary's largest economic centres (Csomós 2015).

\section{Tourism}

Perhaps the most significant advantage of Debrecen's touristic character is that it has good accessibility due to the highways (M35-M3) passing near the city, the railway connections and the presence of the airport. At the same time, it is considered a serious disadvantage that Debrecen provides relatively poor tourist attractions, making it incapable of keeping tourists in the city for a longer time. This situation is perfectly underpinned by the fact that Hajdúszoboszló, a city of 24,000 lying near Debrecen, was visited by 293,000 tourists in 2017 spending 956,000 nights in the city, while, at the same time, Debrecen was visited by only 167,000 tourists spending 374,000 nights in the city. That is, tourists visiting Hajdúszoboszló spent an average of 3.3 nights in the city compared to Debrecen, where tourists spent only an average of 2.2 nights. These differences can be attributed to only one fact: Hajdúszoboszló is home to one of Europe's largest and most well-known thermal spa complexes, while Debrecen, despite having the same geological features, does not yet provide such attractions. Naturally, there are some large events being regularly organised in the city, such as the Flower Carnival, one of Hungary's best-known annual events, and the Campus Festival, the largest music and cultural festival in East Hungary; however, most of them offer only one-day programs for a narrow target audience. No doubt, it is one of Debrecen's most important challenges to improve the tourist attractions offered by the city, and it seems that there are three areas potentially suitable for further developments (Mező, Kovács 2011; MTÜ 2017): health tourism (including medical tourism), thermal spa tourism (a complex thermal spa district is under construction) and cultural tourism (by increasing the number of cultural events). For example, in 2024, Debrecen (in cooperation with Miskolc) will host the European Universities Games, and 
the city is one of the candidates for the European Capital of Culture award of 2023.

Thanks to these developments, Debrecen could be more attractive to tourists who are expected to spend more nights in the city. However, if an increasing number of visitors arrive in Debrecen, it will require significant infrastructure developments, primarily in the public transport system.

\section{Human services}

Debrecen hosts all levels of education institutions. It is home to 48 primary schools and $21 \mathrm{sec}-$ ondary schools, with a total number of more than 23,000 students enrolled not only from the city but also from Hajdú-Bihar County. Furthermore, the University of Debrecen, Hungary's largest university in terms of the number of students, is located in the city. In 2017, the university had approximately 31,000 students, 16 percent of them being foreigners. The number of Hungarian students has not changed for almost one and a half decades (both in 2004 and 2017, the university had 27,000 Hungarian students enrolled), but the number of foreign students has been rapidly increasing (in 2004, there were 1,177 foreign students studying at the university but by 2017 , their number increased to 5,077). Although Wizz Air operates direct flights between Debrecen and, for example, London and Milan, offering the possibility to foreign students to approach the city by plane, most of them however arrive in Budapest by plane and then travel to Debrecen by a doorto-door airport shuttle. One of the main goals of the university is to raise the number of its students to 50,000 by 2050 , but taking account of the fact that it has little chance to increase the number of Hungarian students, the growth will be driven by the increase in the number of foreign students. This grandiose plan suggests that in some decades the number of students at the university will almost double, while the number of foreign students, mostly from Asia and Africa, will increase fivefold. These developments establish new requirements for the airport (e.g. new destinations should be introduced and the quality of the infrastructure should be improved), but also for the railway station, the main transport hub of Debrecen.

In addition, Debrecen has a special role in the national public health system of Hungary.
Debrecen is home to the country's largest medical institution comprising the clinical centre and the university hospital, both operating under the umbrella of the University of Debrecen. Debrecen provides medical services in the whole Northeast Hungarian region for a population of 1.5 million, but in some special fields (e.g. oncology, and cardiology) such services are provided in an even much larger area.

\section{Public administration}

As a city of county rights and the administrative centre of Hajdú-Bihar County, Debrecen holds special administrative status. It is home to the County Government Office (including all of its departments and other subdivisions), the state's administrative body with general jurisdiction. Due to this fact, the administrative functions of Debrecen stretch over the city's border. In addition, Debrecen hosts the headquarters of several county-level public organisations (e.g. the Office of Disaster Management, the Chamber of Commerce and Industry and the HajdúBihar County Archives), while some Debrecenbased public organisations operate in more than one county (e.g. the authorisation area of the Debrecen Court of Appeals covers four counties). Nevertheless, Debrecen does not host any national public organisations. In 2014, the headquarters of the Ministry of Agriculture was going to be relocated from Budapest to Debrecen, but it turned out that the cost of the location change would have been excessive. It seems, however, that Debrecen's ongoing development enforces the occurrence of some high-level administrative functions: having already been home to Russian and Finish consulates, an Israeli consulate has opened in 2018, and the city administration plans to establish a district where foreign consulates can be located.

Finally, we can draw the conclusion that Debrecen has experienced rapid socio-economic developments during the last two decades, and due to these developments, the public transport system of the city faces new challenges. The local economy and some urban functions of Debrecen (e.g. education, culture, public health services, public administration and retail) have significantly strengthened, and the impact area of these functions has been gradually expanding. 
The process is still ongoing. Taking account of the future vision of the city administration and the development plans of some organisations (e.g. companies, the university) located in the city, we can forecast that Debrecen's population, the number of university students, and that of the commuters from neighbouring settlements (whose number already exceeds 40,000 persons per day), will significantly increase. If this robust growth is accompanied by an increase in the number of tourists, the current infrastructure including the public transport system may easily collapse. To avoid this situation, a new type of passenger transport facility, an intermodal passenger terminal, should be created; such a terminal would make it possible for passengers to change transport mode in a short time and provide a wide range of background services. It is not surprising that both Debrecen's Sustainable Urban Mobility Plan, and its Integrated Urban Development Strategy attribute high importance to the creation of the IPT (Debrecen MJV IUDS 2017; Trenecon 2016).

In conclusion, the need for improving Debrecen's public transport system is underpinned by several factors and the process should be based on the creation of an intermodal passenger terminal (IPT). Naturally, this kind of development model is neither novel nor unique. In many countries worldwide, but especially in Europe, the cornerstone of the development of the local public transport system is the implementation of the IPT. In the followings we introduce a new methodology by clustering cities being home to an IPT to present some models being worth benchmarking before creating the IPT in Debrecen. After conducting the cluster analysis, some case studies will be examined thoroughly.

\section{Data and methods}

In recent years, the development of IPTs has been widely spread worldwide, but primarily in countries being home to large urban regions in terms of size and population. These highly suburbanised urban regions in the United States and Australia are generally characterised by the presence of single-storey transport centres having been built on large surface areas (Rivasplata 2001; Henry, Marsh 2008). In Japan, railway stations have become complex station cities, encompassing very large surface areas (Kido 2005, 2015; Tsuchihashi 2003). However, Europe is considered to be the fastest growing market for IPT developments. Based upon the Member States' experiences obtained from ad hoc intermodal transport developments, the European Union has laid down the basic principles to optimise the role of IPTs in the public transport systems (Pitsiava-Latinopoulou et al. 2008; Green, Hall 2009; EC - CORDIS 2012; Pitsiava-Latinopoulou, Iordanopoulos 2012; Lucietti et al. 2016). Due to the national characteristics, IPTs are built, operated and maintained differently worldwide. Furthermore, the transport modes connected within IPTs vary from region to region (for example, trams are not usual transport modes in the United States). Therefore, IPTs may have different impacts on the development of cities they are located in; however, based on a systematic analysis of IPTs worldwide, an empirical classification system can be obtained. In this classification system, the closest samples to the planned IPT of Debrecen are detected and examined as case studies. The analysis is based upon a dataset consisting of 100 samples, out of which 67 IPTs are located in Europe, 21 in Northern America, nine in Australia and three in Japan. When collecting and analysing the data of the samples, we focused on the following characteristics: 1) the population of the city in which the IPT is located, 2) the population of the agglomeration in which the city is located, 3) the area of the city, 4) the geographical position of the IPT within the city, 5) the date and features (e.g. new building, rebuilding) of the IPT construction, 6) the cost of the IPT project, 6) the types of connected transport modes, 7) the number of public transport relations, 8) the number of platforms, 10) the accessibility of international connections, 11) whether transport modes are horizontally or vertically connected, 12) the number of passengers, 13) the types of background services, 14) the presence of park and ride facilities, 15) whether bicycle infrastructure is available and 16) the presence of freight transport.

From the collection of 100 samples, by using cluster analysis, we have chosen some special cases for further and deeper examination. After implementing the Kolmogorov-Smirnov nonparametric test, we applied Ward's method 
for hierarchical cluster analysis. For both the nonparametric test and the cluster analysis, we used IBM SPSS 24 software. On the basis of the number of variables, we examined clusters containing four, five and six elements. To choose the most appropriate result of the cluster analysis, we have implemented discriminant analysis the result of which shows that the cluster with four elements seems to be the most stable one. Based on the distribution of the samples, we realised that Debrecen is in the same cluster with Graz, Linz (both cities being located in Austria) and Poznań (Poland) (Table 1). After carrying out a systematic comparative analysis manually,

Table 1. Main data and features of Ghent, Graz, Linz, Poznań and Debrecen, and that of central railway stations (IPTs) located in those cities.

\begin{tabular}{|c|c|c|c|c|c|}
\hline & Ghent & Graz & Linz & Poznań & Debrecen \\
\hline $\begin{array}{l}\text { population of city } \\
\text { (2016) }\end{array}$ & 257,029 & 282,479 & 198,181 & 538,633 & 201,981 \\
\hline $\begin{array}{l}\text { population of ag- } \\
\text { glomeration (2016) }\end{array}$ & 455,302 & 341,201 & 270,018 & $1,150,348$ & 265,699 \\
\hline area of city $\left(\mathrm{km}^{2}\right)$ & 156.18 & 127.58 & 95.98 & 261.37 & 461.70 \\
\hline $\begin{array}{l}\text { geographical position } \\
\text { of IPT within city }\end{array}$ & $\begin{array}{l}\text { inner city posi- } \\
\text { tion }\end{array}$ & $\begin{array}{l}\text { inner city po- } \\
\text { sition }\end{array}$ & central position & central position & $\begin{array}{l}\text { inner city po- } \\
\text { sition }\end{array}$ \\
\hline $\begin{array}{l}\text { date of IPT construc- } \\
\text { tion }\end{array}$ & $\begin{array}{l}\text { original build- } \\
\text { ing date: } 1912, \\
\text { rebuilding: in } \\
\text { progress }\end{array}$ & $\begin{array}{l}\text { original build- } \\
\text { ing date: } 1956, \\
\text { rebuilding: } \\
2012\end{array}$ & $\begin{array}{l}\text { original build- } \\
\text { ing date: } 1955, \\
\text { rebuilding: } 2004\end{array}$ & $\begin{array}{l}\text { original building } \\
\text { date: } 1879 \text {, rebuild- } \\
\text { ing: } 2012\end{array}$ & $\begin{array}{l}\text { original build- } \\
\text { ing date: } 1849 \text {, } \\
\text { first rebuilding: } \\
\text { 1961, rebuild- } \\
\text { ing to IPTF: un- } \\
\text { der planning }\end{array}$ \\
\hline $\begin{array}{l}\text { features of IPT con- } \\
\text { struction }\end{array}$ & rebuilding & rebuilding & rebuilding & rebuilding & rebuilding \\
\hline $\begin{array}{l}\text { cost of IPT project } \\
\text { (million euros) }\end{array}$ & 496 & 90 & 150 & 152.5 & $\begin{array}{l}\text { 71-113 (project- } \\
\text { ed) }\end{array}$ \\
\hline $\begin{array}{l}\text { connected transport } \\
\text { modes }\end{array}$ & $\begin{array}{l}\text { railway (includ- } \\
\text { ing high-speed } \\
\text { rail), tram, bus, } \\
\text { car, (including } \\
\text { taxi), bicycle }\end{array}$ & $\begin{array}{l}\text { railway, } \\
\text { (including } \\
\text { high-speed } \\
\text { rail), tram, bus, } \\
\text { car, (including } \\
\text { taxi), bicycle }\end{array}$ & $\begin{array}{l}\text { railway, (includ- } \\
\text { ing high-speed } \\
\text { rail), tram, bus, } \\
\text { car, (including } \\
\text { taxi), bicycle }\end{array}$ & $\begin{array}{l}\text { railway, tram, bus, } \\
\text { car, (including taxi), } \\
\text { bicycle }\end{array}$ & $\begin{array}{l}\text { railway, tram, } \\
\text { bus, car, (in- } \\
\text { cluding taxi), } \\
\text { bicycle }\end{array}$ \\
\hline $\begin{array}{l}\text { number of public } \\
\text { transport relations }\end{array}$ & $\begin{array}{l}\text { railway: } 16, \\
\text { tram: } 4 \text {, bus: } 40\end{array}$ & $\begin{array}{l}\text { railway: } 15, \\
\text { tram: } 4 \text {, bus: } 18\end{array}$ & $\begin{array}{l}\text { railway: } 19, \\
\text { tram: } 3 \text {, bus: } 11\end{array}$ & $\begin{array}{c}\text { railway: } 28, \text { tram: } 10 \text {, } \\
\text { bus: } 5\end{array}$ & \\
\hline number of platforms & 12 & 10 & 13 & 16 & \\
\hline $\begin{array}{l}\text { international connec- } \\
\text { tions }\end{array}$ & yes & yes & yes & yes & yes \\
\hline $\begin{array}{l}\text { horizontal or vertical } \\
\text { connections }\end{array}$ & both & both & both & both & both \\
\hline $\begin{array}{l}\text { number of passen- } \\
\text { gers/day }\end{array}$ & 54,169 & 30,000 & 30,000 & 38,356 & 30,000 \\
\hline background services & $\begin{array}{l}\text { shops, coffee } \\
\text { shops, fast food } \\
\text { restaurants, } \\
\text { bookstores, } \\
\text { offices, passen- } \\
\text { ger information } \\
\text { points, apart- } \\
\text { ments }\end{array}$ & $\begin{array}{l}\text { shopping mall, } \\
\text { restaurants, } \\
\text { coffee shops, } \\
\text { gym, personal } \\
\text { services, post } \\
\text { office, passen- } \\
\text { ger informa- } \\
\text { tion points }\end{array}$ & $\begin{array}{l}\text { supermarkets, } \\
\text { fast food restau- } \\
\text { rants, coffee } \\
\text { shops, bakeries, } \\
\text { bank offices, } \\
\text { interior design } \\
\text { shop, travel } \\
\text { agency, book- } \\
\text { store, personal } \\
\text { services }\end{array}$ & $\begin{array}{l}\text { shopping mall, su- } \\
\text { permarket, consumer } \\
\text { electronic store, } \\
\text { shops, offices, fast } \\
\text { food restaurants, cof- } \\
\text { fee shops, bookstore, } \\
\text { bank offices, gym, } \\
\text { passenger informa- } \\
\text { tion points }\end{array}$ & \\
\hline $\begin{array}{l}\text { park and ride facil- } \\
\text { ities }\end{array}$ & yes & yes & yes & yes & yes \\
\hline bicycle infrastructure & yes & yes & yes & yes & yes \\
\hline freight transport & yes & yes & yes & no & yes \\
\hline
\end{tabular}


we found that the characteristics and attitudes of Ghent and the Gent-Sint-Pieters Railway Station (Belgium) are very similar to that of Debrecen and the IPT of Debrecen. However, the IPT of Ghent is still under construction, and therefore the outcome of the project is not yet foreseeable, forcing us to remove it from among the possible case studies (data of the IPT of Ghent can also be seen in Table 1).

Finally, we selected three samples (Graz, Linz and Poznań) out of the four most optimal samples to examine them as case studies. It is common in each IPT sample that transport modes are both horizontally and vertically connected; all transport modes operating in the city are integrated in them, and each of them provides a wide range of background services.

\section{Case studies}

\section{Graz Central Railway Station (2012)}

Graz Central Railway Station lies $2 \mathrm{~km}$ west of the city centre. The urban transport policy of Graz (Austria) is labelled using the slogan 'Gentle Mobility' promoting walking, cycling and the use of public transport, while endeavouring to limit motorised public transport using traffic calming, parking charges and limiting access for cars to the city centre (Sammer 2009). The long-distance bus and regional railway transport systems have great importance because in the Graz agglomeration there are approximately 350,000 people, while Styria, of which Graz is the capital and an economic centre, has a population of more than 1.2 million. Because of the large number of daily commuters (travelling by IC, Railjet, EuroCity and other regional passenger railway services), and the dominance of public transport in Graz, it was necessary to build a high-capacity public transport facility. Graz Central Railway Station, having been delivered to the public in 2012, integrates railway, tram and local bus transport modes, while, by having hundreds of parking spaces, it serves as a solution to the city's parking problems. As an added value to the intermodal transport function, the railway station hosts several background functions, such as shopping malls, restaurants, coffee shops and a post office.

The case of Graz Central Railway Station is noteworthy because the developments have not yet finished, indicating that the implementation of the IPT project can be considered to be the core element of a complex urban development action, rather than a single development goal. In 2014, the ÖBB-Immobilienmanagement, a subsidiary of the Austrian Federal Railways (Österreichische Bundesbahnen - ÖBB) specialised to real estate developments, in co-operation with the local government of Graz, initiated two brownfield development projects to create new city districts near the railway station. The larger district with an area of 16,500 square meters will be located west of the railway station by replacing abandoned and underused manufacturing facilities. As a result of the project, 41,000 square meters of floor area will be built for apartments, offices, hotels and commercial and service facilities (Loukaitou-Sideris et al. 2017). The smaller district (Railway Station Belt) with an area of 9,500 square meters and a total floor area of 21,000 square meters will have similar functions to the larger district. Furthermore, based on the well-developed transport infrastructure, the local government of Graz decided to involve the district in its smart city project under the title Smart City Project Graz Mitte. The main goal of the ongoing smart city developments is to create a near-zero emission city district offering a home to around 1,000 apartments, offices, educational and leisure activities and large green fields. A key element of the project was the building of the 60-meter high Science Tower in 2014, a 100 percent energy efficient building, promoted as the lighthouse of Smart City Graz (http:/ / www. graz-cityofdesign.at/de/output/detail/221/ der-science-tower).

\section{Linz Central Railway Station (2004)}

The geographical position of Linz (Austria) is extremely important because the city is located along a Trans-European transport corridor on the border of Western and Eastern Europe. The local transport system of Linz is highly developed.

As a result of the rebuilding of the Linz Central Railway Station between 1999 and 2004, the tram system and local bus station have been integrated under the same roof, the walking time has been minimised and the change between local and regional transport modes has been accelerated. An important goal of the project was to implement as many additional urban development projects as possible by creating new jobs. While building 
the railway station, a shopping mall and a new urban public space have been created; moreover, a two-storey shopping facility has been built for restaurants, coffees, shops, pharmacies, a tax office and bank offices. Surveys have found that 36 percent of the visitors do not have a travelling purpose, but are interested rather in using additional functions (e.g. shopping, services) of the centre (Klementschitz-Stark 2009; StarkUhlmann 2009).

In tandem with construction of the IPT of Linz, large-scale urban development projects have been implemented around the railway station, being home to scientific and administrative functions. In 2007, a 63-meter high tower, the Wissensturm, was completed to host scientific, educational, leisure functions and cultural programs. In 2008, next to the railway station, the 100-meter high Terminal Tower office building was completed, which is now home to, for example, public services such as the tax office.

\section{Poznań Główny Railway Station (2012)}

Poznań (Poland), a city with a population of almost 540,000, has witnessed significant development due to having been designated as one of the official locations of the 2012 UEFA European Championship. The national development program included 219 projects involving not only Poznań but also such major cities as Gdańsk, Warsaw and Wrocław (Ferrir 2015). In the case of Poznan, one of the flagship projects was the rebuilding of the quasi-monofunctional Poznan Głowny railway station to an intermodal passenger terminal which would be capable of serving as a hub for ICs, ECs, etc. The IPT, integrated with a shopping centre, cost 152.5 million euros, and was completed and opened in October 2013.

Parallel with the IPT project, several developments were implemented affecting not only Poznan itself but its entire agglomeration. The shopping centre has a total floor area of 60,000 square meters and hosts 200 shops being visited by 40,000 people daily. The railway station and bus station are integrated under the same roof and provide parking spaces for 263 cars. On a total area of nine acres, the facility is home to not only the usual transport functions but several cultural events as well. On the ground floor of the three-storey facility, the bus station, the railway platforms and other additional transport services (e.g. ticket offices) can be found. The second floor hosts a police office, shops and left-luggage offices, while the third floor is the location for coffees, restaurants and fast-food restaurants.

These case study projects can serve as examples for the IPT development of Debrecen to model the project possible outcomes and impacts on the development of the city, its agglomeration and the region.

\section{Intermodal Passenger Terminal of Debrecen}

Based on some aspects, the IPT of Debrecen will be a kind of combination of the aforementioned case study projects. However, its unique character will be significantly influenced by the special geographic and socio-economic conditions of Debrecen.

The transport infrastructure of Debrecen is considered to be well-developed. However, the full integration of all transport modes has not yet been carried out; for example, the long-distance bus station is currently located $2 \mathrm{~km}$ from the closest tram station. The main goal of the IPT project is, on the one hand, to improve the local transport options serving the needs of local residents and visitors (e.g. tourists, students and commuters), and, on the other hand, to revitalise the surrounding areas of the railway station, giving new functions to Petófi square (which is one of Debrecen's largest but currently underused urban public spaces). The preparation of the project was initiated approximately one decade ago by performing a number of feasibility studies. After carrying out the engineering plans and other corroborative documents by 2016, all the technical documents are now available to rebuild the railway station and revitalise Petófi square (the exact location and the size of the planning area is illustrated in Fig. 1). The IPT will preserve the architectural structure of the old station building, but by attaching new building sides and creating large transport areas and green fields, the total area of the facility will grow to 150,000 square meters.

One of the most important development components of the IPT project will be the lowering of the major inter-city road No. 4 (E60) under the ground level. This 4-lane road with heavy traffic and high pollution currently divides the urban space lying between downtown and the railway station (of which the main component is Petőfi 
square) into two parts (Fig. 2). By lowering the inter-city road under the ground level, only trams, bicycle and pedestrian lanes will remain at the ground level. The long-distance and local bus stations will be integrated into a new underground station covering a total area of 12,000 square meters. Furthermore, a three-storey parking house with 390 spaces will be built, having both $P+R$ and $\mathrm{K}+\mathrm{R}$ areas. The main terminal of trams is now located opposite the railway station but after the implementation of the IPT project, it will be more harmonically integrated into the station building. Regarding the railway station building, similar to the IPT development of Graz, the project is committed to preserve the architecturally valuable parts of the old building. In the new annexes having a total area of 4,500 square meters, business offices, commercial spaces, administrative offices and restaurants will be installed. Commercial feasibility studies examining the profitable operation of the facility recommend that besides the aforementioned functions, bank offices, bakeries, telecommunication offices, insurance companies, supermarkets, pharmacies, health centres and public service offices (e.g. offices of utility companies, post offices) should be located.

The plans and feasibility studies, however, neglect to examine the further development options of the facility including new real estate developments, logistics and freight forwarding,

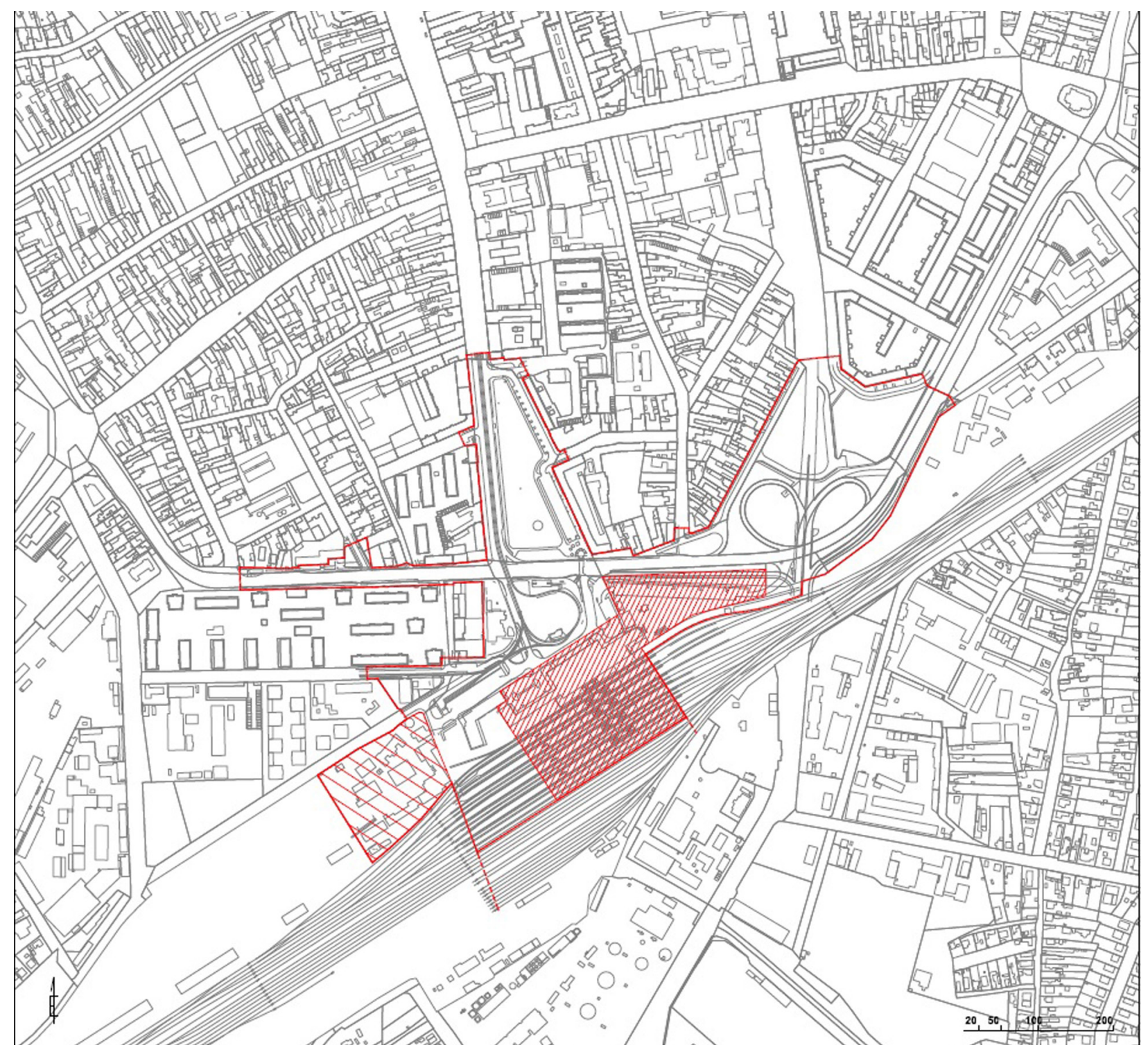

Fig. 1. The exact location and the size of the Debrecen IPT's planning area (centred on the current Main Railway Station). 


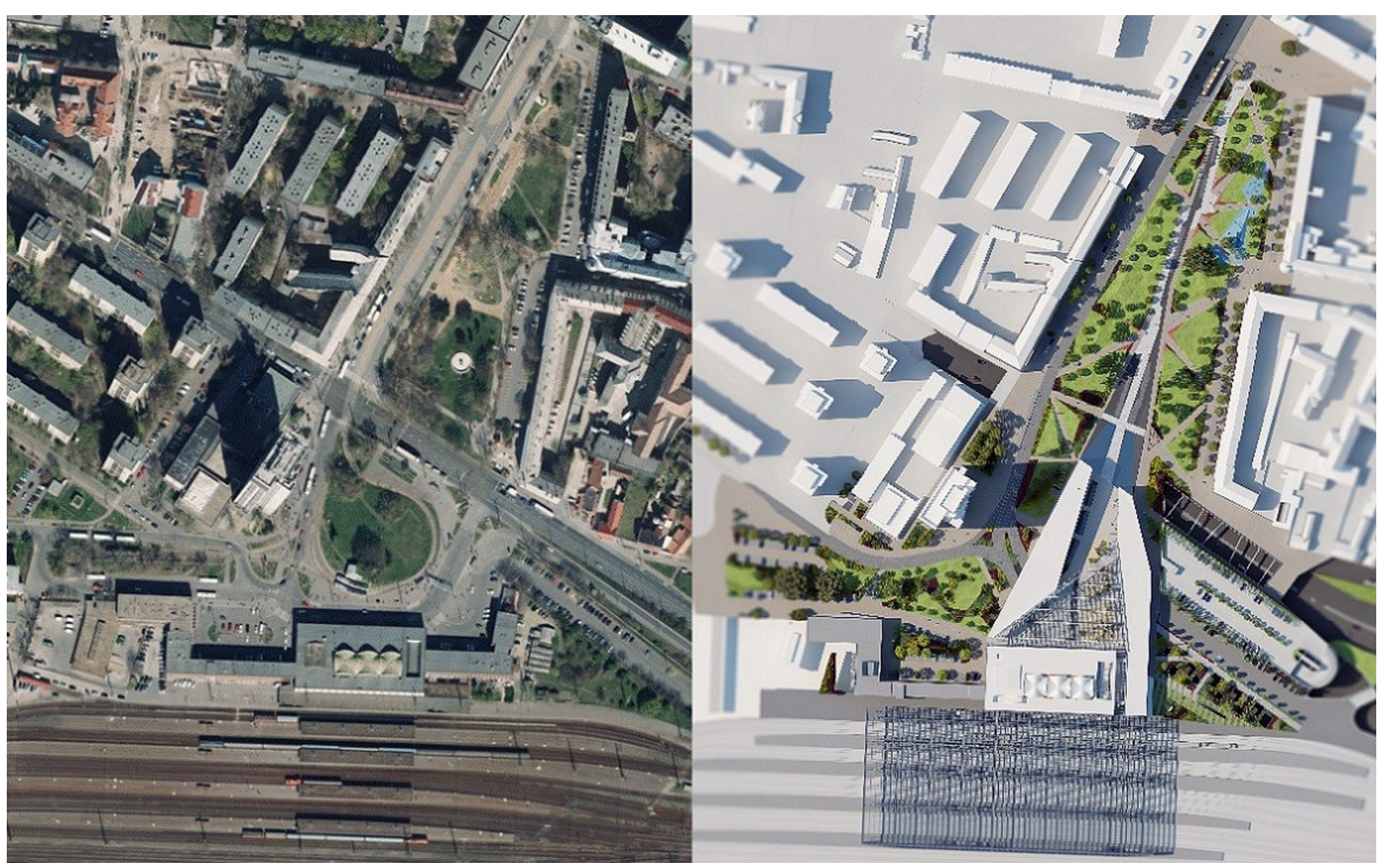

Fig. 2. Current design of the railway station and Petőfi square (left), and a plan of the rebuilt station with the revitalised square (right).

tram train system developments and brownfield revitalisation. In addition, current studies only focus on the feasibility of the IPT project covering the area of the railway station and Petófi square but do not determine the possible impacts of the project on the development of Debrecen out of the scope. In this paper, we place the project in a deeper and wider context, paying more attention to the relationship between the IPT development and the urban functions of Debrecen.

\section{Discussion}

\section{Strengthening of Debrecen's central position in its agglomeration}

According to the Hungarian Central Statistical Office, 12 settlements are located in the agglomeration of Debrecen (Bocskaikert, Ebes, Hajdúbagos, Hajdúhadház, Hajdúsámson, Hosszúpályi, Mikepércs, Monostorpályi, Nyírmártonfalva, Sáránd, Téglás and Vámospércs). There are close functional links between these settlements and Debrecen. In addition, some planning strategies of Debrecen describe a much larger agglomeration in terms of size and the population involving mid-sized cities such as Hajdúböszörmény, Balmazújváros, Hajdúszoboszló and Derecske naming them as outer-ring cities. The central position of Debrecen within the agglomeration, even in its larger metropolitan area, is highly dominant. If we examine whether the urban functions of Debrecen (e.g. public administration, economy, public health services and education) affect settlements located in the agglomeration more intensively due to the implementation of the IPT, the result will probably be neutral. The reason for this assumption is simple: Debrecen, the exclusive provider of many mid- or high-level functions, has no competitors in its region. The question is whether the IPT strengthens Debrecen's central position in the agglomeration by providing mid-level services that are also provided by suburban settlements. The Debrecen IPT will host a Government Window (a physical point of single contact to make it easier for citizens to personally administer their public affairs), a public administration office, giving an additional function to the IPT (similar to the case for Linz).

Because the operation of the Government Windows is based on strict professional 
standards, each of them provides the same services in terms of quality for clients. We assume that if services provided by each Government Window are the same in terms of quality, people who need to administer public affairs will visit the office which they can reach in the shortest time. Currently, two Government Windows operate in Debrecen, and, with respect to the

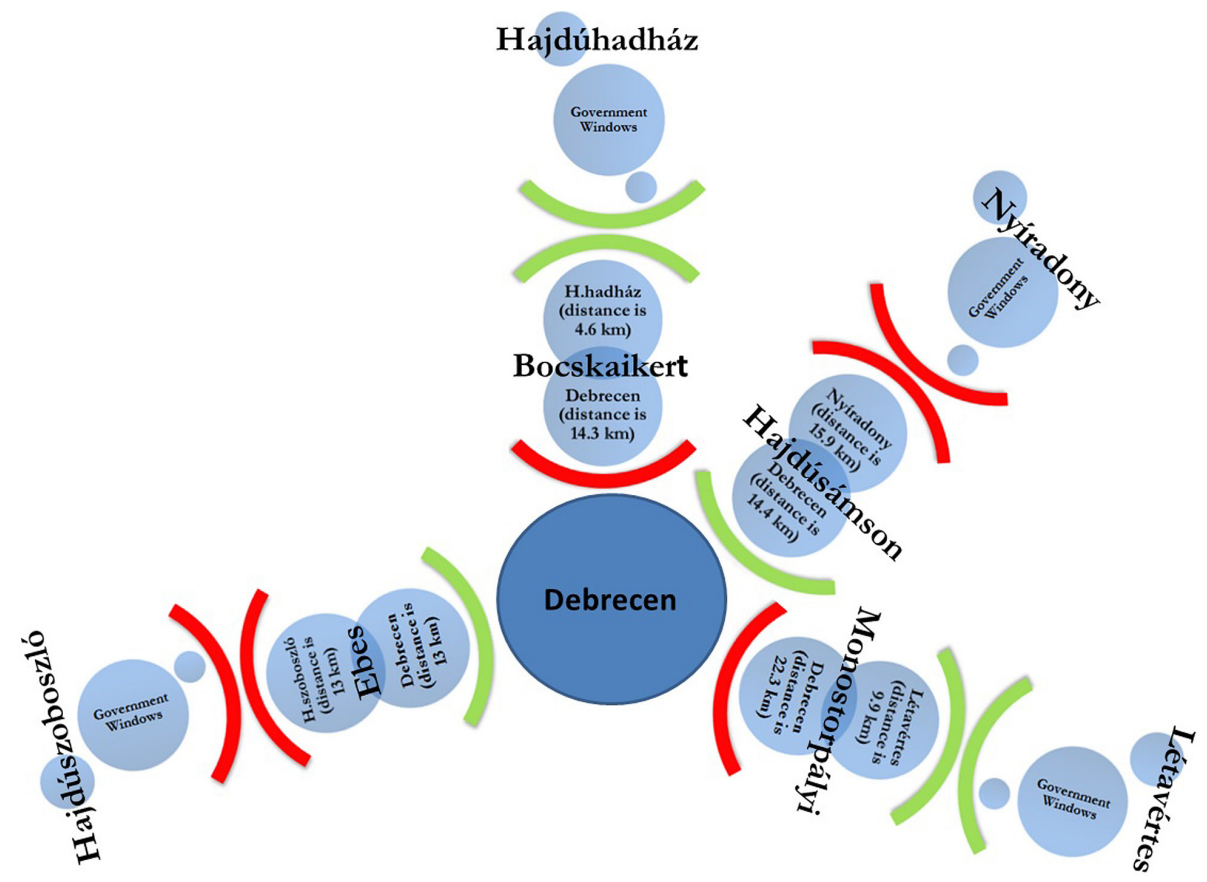

Fig. 3. Geographical distribution of Government Windows located in the northern area of Debrecen's agglomeration (green and red border lines reflect people's expected decisions regarding whether or not they visit the Government Window located in a certain city).

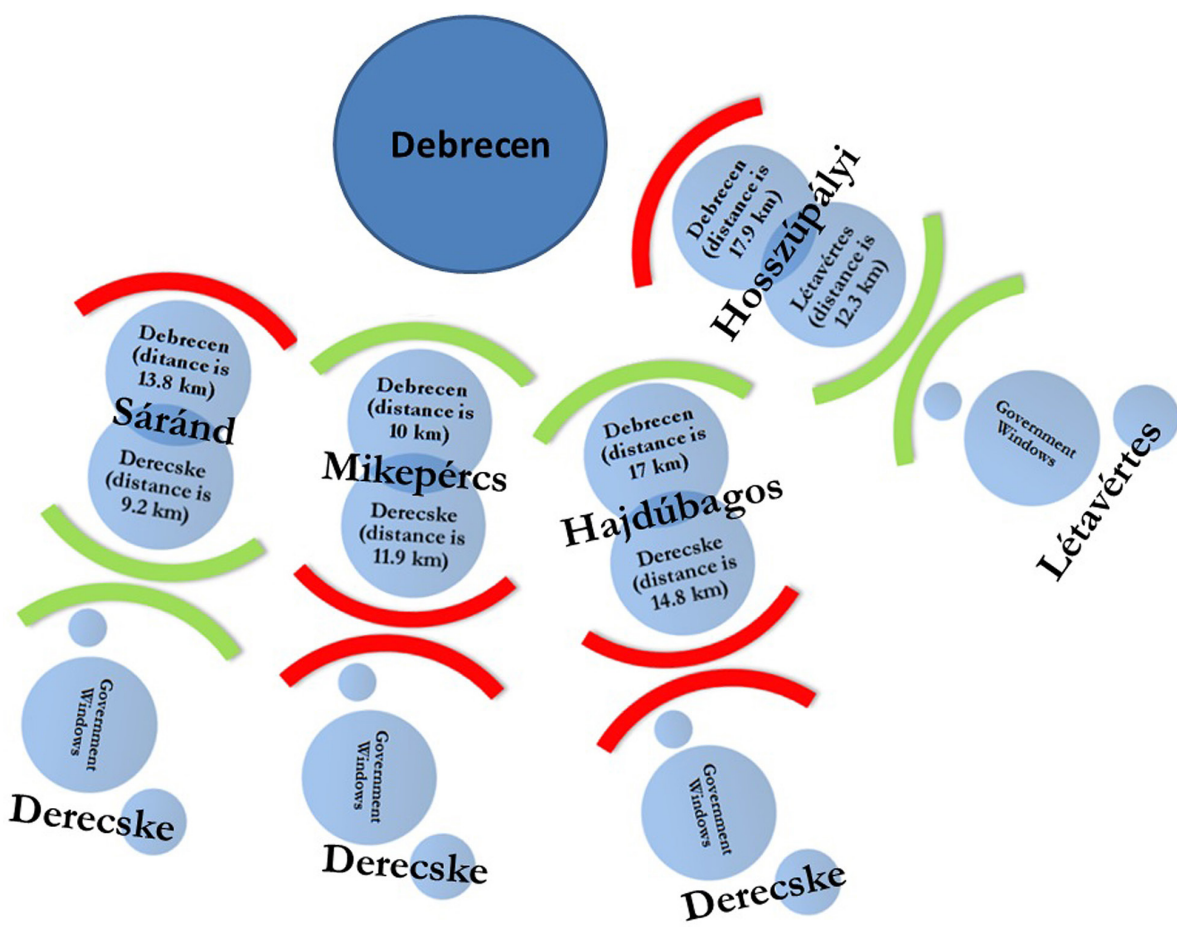

Fig. 4. Geographical distribution of Government Windows located in the southern area of Debrecen's agglomeration (green and red border lines reflect people's expected decisions regarding whether or not they visit the Government Window located in a certain city). 
homogeneous spatial distribution of the public services, offices are located in each outer-ring city as well (except for Téglás and Vámospércs). When planning the Debrecen IPT, it emerged that a new Government Window should be installed in the building on an area of 220 square meters. Therefore, we selected the settlements the inhabitants of which would most probably choose to use the services of the Government Window located in the Debrecen IPT, instead of visiting public offices located in one of the outer-ring cities. We excluded from the analysis the settlements that are located in the agglomeration but their geographical position makes it too difficult for inhabitants to visit the Government Window of the Debrecen IPT. Furthermore, we excluded nine more settlements located in Debrecen's suburban zone from the analysis because these settlements belong to the covering area of Debrecen's local transport system. In total, the analysis involved eight settlements, out of which four have both railway and bus connections but four have only bus connections with Debrecen. Results show that people living in Hajdúsámson (against Nyíradony), Mikepércs and Hajdúbagos (against Derecske) would most probably choose to visit the Government Window in the Debrecen IPT because they could easily reach the office without the need for using public transport services (Figs 3 and 4). In contrast, residents of Bocskaikert, Monostorpályi, Hosszúpályi and Sáránd (against Debrecen) would most probably choose to use the services of Government Windows located in outer-ring cities.

In conclusion, through the services of the Government Window located in the Debrecen IPT, Debrecen's central position in the agglomeration would become more pronounced.

\section{Change of Debrecen's competitiveness in Hungary's urban system}

According to Fenyővári and Lukovics (2008), in the case of a city, the regional competitiveness corresponds to its successful participation in the regional competition by acquiring sustainable economic growth resulting in an increase in GDP and well-being. Cities compete for attracting companies, particularly those producing high added value. Lengyel (2000: 55), based on Porter's theory, noted that the competitiveness of companies significantly depends on the opportunities that cities and their hinterlands can offer because companies have to build their competitive strategy on these factors. When planning the competitive strategy of a company, the production factors, particularly the characteristics of the transport network (transport modes, the quality and quantity of the network) gain high importance. Erdósi (2002) considers that the transport sector significantly influences regional competitiveness. The increasing productivity and employment rate stimulate new investments and broadening services which eventually put pressure on organisations of the transport system to increase supply. Erdősi (2002) suggests that large-scale transport infrastructure developments such as major railways and terminals have high impacts on regional development: companies tend to locate production nearby the large-scale elements of the transport infrastructure, where the number of young, well-educated and creative workforce then start growing, commercial activities increase and information flow accelerates. Intermodal transport solutions both in the case of passenger and freight transport further increase the competitiveness of cities being home to an IPT (Efthymiou-Papatheodorou 2015; Weedy 2018).

The question remains whether the Debrecen IPT would increase the city's competitiveness. Based on the results of international research in the field, the answer should be yes. We consider, however, that in this regard, the Debrecen IPT would not or only weakly increase Debrecen's competitiveness mainly because this city is not only a railway hub, but also an important transport hub, home to an international airport and connected with other large cities through a well-developed highway system. Moreover, in the transport development plans of Debrecen, the development of the airport appears to be more important than that of the railway station. The international airport is located only $2.5 \mathrm{~km}$ from the railway station and it has an increasing dominance in the intermodal logistic development of the city. Hence, the airport is considered to be not only the regional centre of air passenger transport, but also a trimodal logistic hub connecting and integrating flight, railway and road transport modes. Based on this idea, we can assert that it is the airport and not the intermodal 
railway station that provides a competitive advantage for Debrecen against other Hungarian (even Romanian and Slovakian) cities of the same tier. Proving the validity of our hypothesis, the German-based BMW has announced the building of a factory in Debrecen and when looking for the possible location of the factory, one of the most important selection criteria was whether the city has an airport (thus providing the main reason for selecting Debrecen over Miskolc, which does not have an airport). Naturally, there are plans to develop the connection between the airport and the railway station; however, based on the estimated increase in the number of air passengers that the airport could witness in the future, more impetus has been given to the building of a new terminal at the airport. That is, thanks to the changing economic environment which has emerged in Debrecen, it seems that the city administration is prioritising the development of the airport rather than the railway station.

Moreover, in 2018, at one of the world's largest real estate conferences held in Cannes, Debrecen presented plans for a large-scale urban development project called Aeropolis Debrecen that aims to develop a new neighbourhood for business and innovation activities along with residential functions that would surround the area of the airport. Although currently the project exists only as a plan, it determines the future direction of the urban development of Debrecen's southern area.

\section{Change of Debrecen's socio-economic features}

The implementation of the IPT of Debrecen may impact five socio-economic factors of the city: the local manufacturing economy, retail, tourism, administrative functions, and human services (education and public health services). In the previous section, we examined the relationship between the IPT and Debrecen's local economy and came to the conclusion that the creation of the IPT would have hardly any impact on the local economy (excluding the local public transport as a single economic branch). We also examined the relationship between the IPT and the change in the administrative functions of the city. In our opinion, due to the opening of a new Government Window in the IPT and the shortened travelling time, the mid-level administrative functions provided by Debrecen will experience positive changes. In the following section, three more factors (tourism, retail, and human services) will be examined.

In recent years, the tourism industry has gained key importance in the development of the local economy (Balaguer-Cantavella-Jordá 2002; Rogerson 2014) because, due to the direct spending of visitors (accommodation fees, local services and transport) and the taxation incomes, tourism significantly contributes to the increase in the income of the city. The OECD (2016: 4) highlights the relationship between intermodality and tourism: "By promoting the development of intermodal hubs and gateways, transport policies (e.g. integrated multimodal transport systems) at the national and sub-national level can not only help attract, manage or direct visitor flows but also facilitate a shift to more eco-friendly transport options, which can help consolidate a destination's reputation as sustainable." Those visitors who arrive in Debrecen by train or by scheduled long-distance bus services will enter the city through the IPT and this experience may influence their impression of the city. In our opinion, the IPT development as a single project will not significantly influence the tourism industry of Debrecen, but the urban renewal projects accompanying the IPT development will have a positive impact. However, an IPT is a necessary infrastructural element of modern tourism because it contributes to create comfortable conditions for visitors, shortens tourists' time required for changing transport modes and serves as a base point to reach potential destinations in the city.

Most international research and strategies consider intermodality as a tool enhancing the efficiency of freight transport, but in the case of Debrecen, the IPT development will primarily be in relationship with retail because freight transport is marginal in the city (there is no port in Debrecen). The probable increase in the retail industry is due to two reasons: on the one hand, the IPT building will host retail functions (e.g. shops, coffee shops, fast food restaurants and bookstores) on a floor area of 3,000 square meters and, on the other hand, it will become significantly more easy to approach shopping centres and malls, as well as other hypermarkets. People arriving from the surrounding settlements to 
Debrecen by bus will have the possibility to change to local buses, trolley-buses or trams (the latter transport mode is currently available directly for commuters coming to Debrecen by train), each of which passes retail locations in the city centre. Regarding some subtypes of the retail industry (e.g. clothing and apparel retail, and furniture retail), Debrecen has cross-border impact attracting shoppers primarily from Romania and Ukraine (a more in-depth analysis on the reasons surrounding this issue is carried out by Bar-Kołelis, Wendt (2018)). The IPT will host 384 park-and-ride parking spaces on an area of 5,500 square meters, making it possible for visitors arriving by car to continue their journey in the city by one of the public transport modes.

Finally, we should highlight that Debrecen has a special role in Hungary regarding human services. As mentioned previously, the secondary schools located in Debrecen attract students not only from Debrecen but all over HajdúBihar County (Teperics 2008). The IPT will make it much easier for commuter students to reach the location of their schools because they will be able to change public transport modes in a single building (if coming to Debrecen by bus, currently many commuter students must change more than once to reach their schools). In addition, when examining the relationship between Debrecen's educational services and the future operation of the IPT, the role of the University of Debrecen should be examined more thoroughly. The University of Debrecen is the largest university in Hungary in terms of the total number of students (approximately 30,000) and the number of foreign students (about 5,000). It is one of the main strategic goals of the university to increase the number of foreign students. We consider that the travelling habits of Hungarian university students correspond to that of the students enrolled in secondary schools (i.e. the need for changing transport mode in a single building), but the functions of the IPT are irrelevant for foreign students because some of them arrive in Debrecen by plane (entering the city through its international airport) and the majority of them travel by airport shuttle (entering Hungary through Liszt Ferenc International Airport in Budapest). In the first case, they reach their final destination in the city by taxi or a scheduled airport bus, while in the latter case, the shuttle takes them directly to the final destination. In any case, foreign students do not often choose to travel to Debrecen by train and for this reason the creation of the IPT is irrelevant for them. However, travelling by train would be more competitive and attractive if the infrastructure of the Budapest-Debrecen railway and the comfort level of trains were improved (Givoni 2006), but these developments are out of Debrecen's scope and should be implemented by Hungarian State Railways.

\section{Enhancement of spatial polycentricity of Debrecen's cultural activities}

Several studies in the field suggest that Debrecen is a city with complex cultural functions (Gombos 2016) and therefore hosts most segments of its cultural industry (i.e. libraries, museums, theatres, public cultural institutions, cinemas, built heritages, art relics and festivals). However, the city cannot provide the tourist attractions that would motivate tourists to stay in Debrecen more than for three days. Therefore, it is highly important to develop tourist attractions, primarily cultural ones. While libraries and public cultural institutions have a dispersed location pattern in the city, museums and theatres are located in the city centre exclusively and most cultural events are organised in the city centre as well. Besides the outstanding cultural function of the 'Downtown' district, the only area of Debrecen showing a significant cultural attitude is the 'Great Forest Park' in the northern area of the city. Therefore, it is not surprising that Debrecen's cultural strategy attributes great importance to the decentralised development of the city's cultural attractions (Debrecen MJV Cultural Strategy 2018).

According to the feasibility study of the Urban Development Concept (UDC) of 2014-2020 and the Integrated Urban Development Strategy (IUDS) of 2014-2020, the 'Ispotály' district in which the IPT will be located faces some problems that negatively affect the appearance of some of the following cultural functions: the low number of parking spaces, the deteriorated condition of urban green spaces and the lack of public spaces (Debrecen MJV UDC/IUDS Feasibility Study 2014; Debrecen MJV UDC 2014; Debrecen MJV IUDS 2017). Neither the feasibility study 
nor the UDC and the IUDS consider the lack of tourism infrastructure as a weakness of the district. Furthermore, the development strategies of Debrecen neglect to designate the revitalised Petófi square as a public place where cultural events can be organised. Both the UDC and IUDS declare that 14 out of the 25 major cultural developments of the 2014-2020 period should be located in the 'Downtown' area (e.g. concert hall, outdoor theatre and performing arts centre), while the 'Great Forest Park' should be home to five of them. The locations of three more developments have not been decided, and only three developments will be located out of the 'Downtown' and 'Great Forest Park' districts (Debrecen MJV Cultural Strategy). In addition, Debrecen plans to initiate four new festivals in the future out of which three will be organised in the 'Downtown' and 'Great Forest Park' districts. If Debrecen is committed to decentralising cultural attractions, it should involve more public spaces for cultural events and designate increased numbers of districts as home to new cultural developments. In addition, some studies suggest that both 'Downtown' and 'Great Forest Park' areas are overloaded and overcrowded, and suffer from noise and air pollution.

It is a worldwide trend that intermodal passenger terminals serve not only as places for travelling but also as locations for additional activities, for example, business, retail, leisure and tourism (Terrin 2014; OECD 2016). For instance, the IPT of Lisbon hosts cinemas, a book market and art gallery; cinemas can also be found in the Arnhem IPT; there are cultural spaces in the IPT of Freiburg, Vienna and Madrid, and the IPT of Zaragoza is home to a museum. However, in Europe, it is rather exceptional to install cultural functions in IPTs and general examples show that such functions are more likely to occur on renewed and revitalised areas surrounding IPTs (for example, many cultural events are organised near the IPTs of Graz, Liège, Rotterdam and Strasbourg).

The IPT of Debrecen will also host several leisure functions to help travellers spend their waiting time in a useful manner, but regarding the location of cultural functions, the revitalisation of Petófi square appears to be more important. Currently, Petófi square is divided into two parts due to the fact that the inter-city road No. 4 (E60) cuts through the square. By lowering the road under the ground level, a new public space can be created on a total area of 36,000 square meters, allowing the city to organise large-scale cultural events on the square. The involvement of Petófi square into Debrecen's network of cultural spaces can contribute to the decentralisation of cultural attractions, making the city more polycentric with respect to culture.

\section{Conclusion}

Due to socio-economic changes emerging in the 21st century, cities face new challenges and new expectations regarding transport, particularly public one arise. These expectations are as follows: to shorten the time required for changing transport modes, to provide a wide range of background services for travellers to spend their waiting time more usefully, to increase the comfort-level of transport facilities and to minimalise urban areas required for transport infrastructure. In response to these challenges, public transport all around the world but particularly in Europe has turned toward an intermodal approach. European cities tend to implement intermodal solutions in local public transport and in this process, intermodal passenger terminals have key importance. IPTs are considered to be hubs and integrating interfaces in the network of the public transport system where travellers could change transport modes and which have more complex functions than simply transport. European examples show that IPT developments are not isolated projects but rather core elements of large-scale urban renewal actions such as complex smart city developments.

By building an IPT in Debrecen, the largest Hungarian transport development project will be implemented in the EU programming period of 2014-2020. The significance of the project is underpinned by the fact that it is considered the most important key project of the city (i.e. the project the outcome of which influences the implementation of all other urban developments). Many feasibility studies and pre-examination reports focusing on the IPT development have been performed because of its long construction time, high construction costs and planned impacts on the local public transport system. However, we 
have not found a single work examining the relationship between the implementation of the IPT and the accompanying urban renewal projects and the middle- or long-term development of Debrecen.

In our study, we have thoroughly evaluated these topics and as a result we conclude that the IPT development will generate three types of impacts in terms of strength (weak, medium and strong) and these impacts will be reflected at four different spatial levels: local (Debrecen), regional (covering Hajdú-Bihar County at least), national (Hungary) and international (primarily Romania and Ukraine) (Table 2).

Due to the increasing capacity of the mid-level administrative functions, it is suspected that Debrecen's central position will enhance its agglomeration. However, because the mid-level administrative functions only serve the requirements of the population of the surrounding settlements, the strength of the impact of the Government Window installed in the IPT is considered medium and affects the local level.

Regarding the change of Debrecen's competitiveness, the impact of the IPT is weak and affects the regional level because the IPT in itself cannot improve the quality of the railway transport (speed, comfort-level, etc.) while Debrecen is accessed via Budapest and other large cities by a well-developed highway system. In addition, compared with its domestic competitors (i.e. Kecskemét, Miskolc, Nyíregyház and Szeged), Debrecen hosts an international airport which provides a competitive advantage for the city.

With respect to Debrecen's metropolitan functions (commerce, education and public health services) and the development of the local economy including the tourism industry, the IPT can generate positive impacts with cross-border effects. Since the end of the 2000s, Debrecen has become one of the major hubs for commerce and retail activities and has been visited by many shopping tourists from Romania and Ukraine (Tömöri 2010). The IPT will host almost 400 parking spaces, making it possible for foreigners and residents living in the agglomeration to, after parking their cars, continue their journey in the city by one of the public transport modes (primarily by trams that pass offices, banks and the main shopping centres in the city centre). We consider that regarding the needs of firms, the implementation of the IPT will be neutral because the basic transport functions are adequately provided by the current railway station; moreover, for most firms, the highway connection and the location of the airport are more important.

The IPT, or more precisely the urban renewal projects accompanying the IPT development, will have the most significant impact on the decentralisation of cultural activities in the city. Debrecen is considered one of Hungary's major cultural centres and by applying to the European Capital of Culture award of 2023, the city is attempting to position itself among the international cultural centres. The two main locations of cultural institutions and activities in the city are the 'Downtown' and the 'Great Forest Park' districts, both of which are overloaded and overcrowded, and suffer from noise and air pollution. The renewed and revitalised Petófi square in front of the IPT building would provide a highly suitable location for large cultural events and by becoming a vivid public space, it could provide a counterweight to the 'Downtown' area (the theoretical background of ReUrbanism projects is thoroughly explained by Haas, Locke 2018).

The financial problems, however, seriously jeopardise the implementation of the project: the originally estimated budget of the project was HUF 22 billion (approximately EUR 67 million), but after conducting the public procurement, it turned out that even the cheapest bid was higher than HUF 34 billion (approximately EUR 107 million). Because of the rapid increase in construction costs experienced in Hungary in recent years, the public procurement process must be conducted again (the process which is still currently in progress) (Bodnár, Csomós 2018).

Table 2. Matrix of impacts generated by IPT on urban development of Debrecen.

\begin{tabular}{|l|c|c|c|c|}
\hline & Local & Regional & National & International \\
\hline Debrecen's central position in its agglomeration & medium & & & \\
\hline Debrecen's competitiveness & & weak & & \\
\hline Debrecen's socio-economic features & & & & medium \\
\hline Debrecen's cultural polycentricity & strong & & & \\
\hline
\end{tabular}


In conclusion, the creation of the intermodal passenger terminal in Debrecen and the urban renewal projects surrounding the IPT building would positively influence the urban development of Debrecen.

\section{Acknowledgement}

This publication is supported by the EFOP3.6.1-16-2016-00022 project. The project is co-financed by the European Union and the European Social Fund.

\section{References}

Balaguer J., Cantavella-Jordá M., 2002. Tourism as a long-run economic growth factor: The Spanish case. Applied Economics 34(7): 877-884. https://doi. org/10.1080/00036840110058923

Bar-Kołelis D., Wendt J.A., 2018. Comparison of cross-border shopping tourism activities at the Polish and Romanian external borders of European Union. Geographia Polonica 91(1): 113-125. https://doi.org/10.7163/GPol.0103

Bertolini L., Dijst M., 2003. Mobility environments and network cities. Journal of Urban Design 8(1): 27-43. https:/ / doi.org/10.1080/1357480032000064755

Bertolini L., 1996. Nodes and places: Complexities of railway station redevelopment. European Planning Studies 4(3): 331-345. https://doi.org/10.1080/09654319608720349

Bodnár B., 2017. Az intermodális közösségi közlekedési központok értelmezése. Jelenkori társadalmi és gazdasági folyamatok 12(3): 189-201.

Bodnár B., Csomós G., 2018. Az intermodális közösségi közlekedési központ lehetséges hatásai Debrecen fejlődésére. Területi Statisztika 58(5): 505-538. https://doi. org/10.15196/TS580504

Bontekoning Y.M., Macharis C., Trip J.J., 2004. Is a new applied transportation research field emerging? - A review of intermodal rail-truck freight transport literature. Transportation Research Part A: Policy and Practice 38(1): 1-34. https://doi.org/10.1016/j.tra.2003.06.001

Browning J., 2016. Global Logistics \& Trade: Intermodal Transport. CreateSpace Independent Publishing Platform, Seattle.

Caris A., Macharis C., Janssens G.K., 2008. Planning problems in intermodal freight transport: Accomplishments and prospects. Transportation Planning and Technology 31(3): 277-302. https:// doi.org/10.1080/03081060802086397

Csomós G., 2015. The ranking of cities as centres of the Hungarian economy, 1992-2012. Regional Statistics 5(1): 66-85. https://doi.org/10.15196/RS05104

Dacko S.G., Spalteholz C., 2014. Upgrading the city: Enabling intermodal travel behaviour. Technological Forecasting and Social Change 89: 222-235. https://doi.org/10.1016/j. techfore.2013.08.039

Debrecen MJV Cultural Strategy, 2018. Debrecen Megyei Jogú Város Kulturális Stratégia 2018-2030. Társadalmasitási változat. Online: https:/ /www.debrecen.hu/assets/media/ file/hu/10308/debrecen-megyei-jogu-varos-kulturalis-strategia-2018.pdf (accessed: 25 June 2018).
Debrecen MJV UDC/IUDS Feasibility Study, 2014. Debrecen Megyei Jogú Város Településfejlesztési Koncepciója és Integrált Településfejlesztési Stratégiája 2014-2020 Megalapozó Vizsgálat. Online: https://www.debrecen.hu/assets/ media/file/hu/4821/debrecenmjv-its-megalapozo-vizsgalat-melleklettel.pdf (accessed: 12 May 2018).

Debrecen MJV UDC, 2014. Debrecen Megyei Jogú Város Településfejlesztési Koncepciója 2014-2020. Online: https:/ / www.debrecen.hu/assets/media/file/hu/7309/koncepcio.pdf (accessed: 12 May 2018).

Debrecen MJV IUDS, 2017. Debrecen Megyei Jogú Város Integrált Településfejlesztési Stratégiája 2014-2020. Akcióterületek kijelölésével kapcsolatos technikai módosítás, 2017. Online: https://www.debrecen.hu/assets/media/file/hu/7308/strategia.pdf (accessed: 12 May 2018).

de Langen P.W., Lases Figueroa D.M., van Donselaar K.H., Bozuwa J., 2017. Intermodal connectivity in Europe, an empirical exploration. Research in Transportation Business and Management 23: 3-11. https://doi.org/10.1016/j. rtbm.2017.02.003

Dohány M., Kádi O., 2016. IMCS (r)evolúció. Városi közlekedés 2016/12: 38-41.

EC (European Commission) - CORDIS., 2012. Innovative design and operation of new or upgraded efficient urban transport interchanges: New tools for design and operation of urban transport interchanges (Project ID: 314618); City-HUB (Project ID: 314262). Online: https://cordis.europa.eu/programme/rcn/18086_en.html (accessed: 12 May 2018).

Efthymiou M., Papatheodorou A., 2015. Intermodal passenger transport and destination competitiveness in Greece. Anatolia 26(3): 459-471. https://doi.org/10.1080/130329 17.2015.1012171

Enyedi Gy., 2011. A városnövekedés szakaszai - újragondolva. Tér és Társadalom 25(1): 5-19.

Erdősi F., 2002. Gondolatok a közlekedés szerepéről a régiók/városok versenyképességének alakulásában. Tér és Társadalom 16(1): 135-159.

ESIF (European Structural and Investment Funds) Data, 2018. Network Infrastructure in Transport and Energy. Online: https://cohesiondata.ec.europa.eu/themes/7 (accessed: 9 July 2018).

Fenyővári Zs., Lukovics M., 2008. A regionális versenyképesség és a területi különbségek kölcsönhatásai. Tér és Társadalom 22(2): 1-20.

Ferrir R., 2015. Major infrastructure changes occurring in Polish host cities in connection with the staging of Euro 2012. MPRA Paper 68209. Munich Personal RePEc Archive, University Library of Munich.

Fleischer T., 2006. A vasúti pályaudvarok új szerepe a kibővített Európai Unióban. Európai Tükör 11(5): 53-63.

Ghaderi H., Cahoon S., Nguyen H.O., 2016. The role of intermodal terminals in the development of non-bulk rail freight market in Australia. Case Studies on Transport Policy 4(4): 294-305. https://doi.org/10.1016/j. cstp.2016.09.003

Givoni M., 2006. Development and impact of the modern high-speed train: A review. Transport Reviews 26(5): 593611. https:// doi.org/10.1080/01441640600589319

Gombos Sz., 2016. A kulturális szolgáltatások kínálata közötti különbségek a magyarországi tízezer fő feletti városokban. Területi Statisztika 56(5): 565-587. https:// doi.org/10.15196/TS560504

Green C., Hall P., 2009. Better Rail Stations Department for Transport, London, Online: http:/ / webarchive.national- 
archives.gov.uk/20101007153226/http://www.dft.gov. $\mathrm{uk} / \mathrm{pgr} / \mathrm{rail} /$ passenger/stations/betterrailstations/ (accessed: 6 July 2018).

Haas T., Locke R., 2018. Reflections on the ReUrbanism paradigm: Re-weaving the urban fabric for urban regeneration and renewal. Quaestiones Geographicae 37(4): 5-21. https://doi.org/10.2478/quageo-2018-0037

Heddebaut O., Palmer D., 2014. Multimodal city-hubs and their impact on local economy and land use. HAL. Online: https://hal.archives-ouvertes.fr/hal-01073030 (accessed: 17 July 2018).

Henry L., Marsh D.L., 2008. Intermodal surface public transport hubs: Harnessing synergy for success in America's urban and intercity travel. In: 2008 American Public Transportation Association (APTA) Bus \& Paratransit Conference. American Public Transportation Association, Austin TX: $1-13$.

Kido E.M., 2005. Aesthetic aspects of railway stations in Japan and Europe, as a part of "context sensitive design for railways". Journal of the Eastern Asia Society for Transportation Studies 6: 4381-4396.

Kido E.M., Cywiński Z., 2014. The new steel-glass architecture of railway stations in Japan. Steel Construction 7(3): 208-214. https://doi.org/10.1002/stco.201420022

Klementschitz R., Stark J., 2009. Public transport systems development for urban regeneration - evidence from the city of Linz/Austria. REAL CORP 2009: CITIES 3.0 - Smart, Sustainable, Integrative Strategies, concepts and technologies for planning the urban future. Online: https:/ / www.corp. at/archive/CORP2009_12.pdf (accessed: 12 April 2018).

Lengyel I., 2000. Porter-rombusz: a regionális gazdaságfejlesztési stratégiák alapmodellje. Tér és Társadalom 14(4): 39-86.

Li L., Negenborn R.R., De Schutter B., 2015. Intermodal freight transport planning - A receding horizon control approach. Transportation Research Part C: Emerging Technologies 60: 77-95. https://doi.org/10.1016/j. trc.2015.08.002

Loukaitou-Sideris A., Peters D., Colton P., Eidlin E., 2017. A comparative analysis of high-speed rail station development into destination and multi-use facilities: The case of San Jose. Diridon Mineta Transportation Institute Publications. Online: http://scholarworks.sjsu.edu/cgi/ viewcontent.cgi? article $=1223 \&$ context $=$ mti_publications (accessed: 8 May 2018).

Lucietti L., Hoogendoorn C., Cré I., 2016. New tools and strategies for design and operation of urban transport interchanges. Transportation Research Procedia 14: 1240 1249. https://doi.org/10.1016/j.trpro.2016.05.195

Mező F., Kovács T., 2011. Az egészségturizmus, mint lehetséges kitörési pont az Észak-alföldi régióban. Debreceni Szemle 19(2): 208-225.

MTÜ (MAGYAR TURISZTIKAI ÜGYNÖKSÉG), 2017. Nemzeti Turizmusfejlesztési Stratégia, 2030. Magyar Turisztikai Ügynökség, Budapest. Online: http:/ / www.kormany.hu/download/8/19/31000/mtu_kiadvany_EPUB_297x210mm\%20-\%20preview.pdf (accessed: 03 July 2018).

Nobis C., 2007. Multimodality: Facets and causes of sustainable mobility behaviour. Transportation Research Record 2010: 35-44. https://doi.org/10.3141/2010-05

OECD, 2016. Intermodal connectivity for destinations OECD Centre for Entrepreneurship. SMEs and Local Development, Paris.
Páthy A., 2017. Types of development paths and the hierarchy of the regional centres of Central and Eastern Europe. Regional Statistics 7(2): 124-147. https://doi. org/10.15196/RS070202

Pitsiava-Latinopoulou M., Zacharaki E., Basbas S., Politis I., 2008. Passenger intermodal terminal stations: Role and infrastructure. WIT Transactions on the Built Environment, 101: 233-242. https://doi.org/10.2495/UT080231

Pitsiava-Latinopoulou M., Iordanopoulos P., 2012. Intermodal Passengers Terminals: Design standards for better level of service. Procedia - Social and Behavioral Sciences 48: 3297-3306. https://doi.org/10.1016/j.sbspro.2012.06.1295

Rivasplata C.R., 2001. Intermodal transport centres: Towards establishing criteria. In: 20th Annual South African Transport Conference 2001. Meeting the Transport Challenges in Southern Africa. SATC, Pretoria: 1-12.

Rogerson C.M., 2014. Reframing place-based economic development in South Africa: The example of local economic development. Bulletin of Geography. Socio-economic series 24: 203-218. https://doi.org/10.2478/bog-20140023

Sammer G., 2009. Non-negligible side effects of traffic demand management. In: Saleh W., Sammer G. (eds), Travel demand management and road user pricing: Success, failure and feasibility. Ashgate Publishing, Farnham-Burlington, VT: 13-36.

Stark J., Uhlmann T., 2009. Railway stations of the future services supporting intermodal travelling and promising strategies for their development. REAL CORP 2009: CITIES 3.0 - Smart, Sustainable, Integrative Strategies, concepts and technologies for planning the urban future. Online: https:// programm.corp.at/cdrom2009/papers2009/ CORP2009_13.pdf (accessed: 12 April 2018).

Sugawara J., 2017. Port and hinterland network: A case study of the Crescent Corridor intermodal freight program in the US. Transportation Research Procedia 25: 916-927. https:/ / doi.org/10.1016/j.trpro.2017.05.466

Teperics K., 2008. Debrecen oktatási vonzáskörzete TERD projekt, a Területi statisztikai alprogram eredményei, Debreceni Egyetem, Online: http://terd.unideb.hu/ doc/de_okt_vonzask.pdf (accessed: 16 May 2018).

Terrin J.-J., 2014. High speed mobility and urban planning thematic report. ENTER.HUB European Network exploiting Territorial Effects of Railway Hubs. Online: urbact.eu/ file/9612/download?token=pUx1YNt5 (accessed: 26 June 2018).

The Financial Times, 2018. fDi European Cities and Regions of the Future 2018/19. The Financial Times, London. Online: https://www.fdiintelligence.com/Locations/Europe/fDi-s-European-Cities-and-Regions-of-the-Future2018-19-FDI-Strategy-Cities (accessed: 28 July 2018).

Tömöri M., 2010. Investigating shopping tourism along the borders of Hungary - a theoretical perspective. GeoJournal of Tourism and Geosites 6(2): 202-210.

Trenecon, 2016. Debrecen Fenntartható Városi Mobilitási Terve. Trenecon, Budapest: 156.

Tsuchihashi K., 2003. Evolution theory of train stations. Contemporary Architecture 57(3): 84-85.

Weedy S., 2018. EU/US alliance: 'intermodal transport vital for competition'. Railfreight.com. Online: https://www. railfreight.com/policy/2018/02/06/eu-us-alliance-intermodal-transport-vital-for-competition/ (accessed: 25 June 2018). 